\title{
Importance of indigenous communities' knowledge and perception in achieving biodiversity conservation: A case study from Manobo tribe of Southern Mindanao, Philippines
}

\author{
FLORENCE ROY P. SALVAÑ $A^{1,2,3, \boldsymbol{v}}$, SHANE LOVE T. ARNIBAL ${ }^{4}$ \\ ${ }^{1}$ Department of Biological Sciences, College of Arts and Sciences, University of Southern Mindanao, Kabacan Cotabato, Philippines. \\ Tel.: +62-64-572-2138, `email: rdsalvana@usm.edu.ph \\ ${ }^{2}$ Graduate School, University of the Philippines Los Baños, College, Laguna, Philippines \\ ${ }^{3}$ Philippine Council for Agriculture, Aquatics and Natural Resources Research and Development (DOST-PCAARRD). Brgy. Timugan, Los Baños, \\ Laguna, Philippines \\ ${ }^{4}$ Department of Secondary Education, College of Education, University of Southern Mindanao. Kabacan Cotabato, Philippines
}

Manuscript received: 14 Oktober 2019. Revision accepted: 11 November 2019.

\begin{abstract}
Salvaña FRP, Arnibal SLT. 2019. Importance of indigenous communities' knowledge and perception in achieving biodiversity conservation: A case study from Manobo tribe of Southern Mindanao, Philippines. Asian J Ethnobiol 2: 84-91. Indigenous communities play a relevant role in setting biodiversity management and conservation. This study aims to determine the knowledge and perceived importance of the Manobo tribe toward biodiversity. A total of 100 Manobos were included in the study to assess indigenous communities' ability and perception, particularly the Manobo tribe towards biodiversity. A semi-structured survey questionnaire was used to determine responses on knowledge and importance perception/ Our study found a consistent significant difference in the mean responses on knowledge and perception across gender and education attainment. Interestingly, traditional knowledge is significantly associated with the biodiversity importance perception of Manobos. Our findings suggest involving indigenous communities is equally important in achieving balanced biodiversity conservation and protection. Thus, strengthening collaborations among local government sectors and community leaders must develop conservation priorities and protection.
\end{abstract}

Keywords: Biodiversity, conservation, knowledge, Manobo, perception

\section{INTRODUCTION}

Biodiversity supports the health of ecosystems and the services they provide to society. However, biodiversity is in rapid decline globally, despite commitments by governments to reduce the rate of loss (Butchart et al., 2010). Monitoring is an essential part of biodiversity conservation, allowing governments and civil society to identify problems, develop solutions, and assess the effectiveness of actions and progress toward meeting the Convention on Biological Diversity (Secades et al. 2014). The Philippines' biodiversity heritage is globally essential due to high species endemicity and concentration of threatened species (Myers et al. 2000; Garrity 2001; Posa et al. 2008). However, the establishment of protected areas alongside the implementation of policies towards limiting biodiversity threats, yet human activities (e.g., deforestation, agricultural expansions) remain to persist in many country regions. The protection of species and habitats provides the essential backdrop to existing biodiversity conservation management strategies and policies globally (Bille et al., 2012). Traditionally, conserving nature has been equated with protecting charismatic and rare species or protecting their habitats and spectacular landscapes (Shafer 1990; Home et al. 2009). However, one of the current challenges in decision-making is the limited and inadequate human and financial resources to protect particular species or invest in the management and protection of habitats that are of substantial biological value (Jaisankar et al., 2018).

Considering that ancestral lands and territories contain $80 \%$ of the planet's biodiversity, indigenous people can play a crucial role in conserving and sustainable management of natural resources (IFAD 2014; Garnett et al. 2018). Indigenous people play an essential role in regenerating their natural resources and ancestral environments and systems (Russell et al., 2015). Indigenous people often inhabit territories rich in minerals and natural resources; thus, they have in-depth, varied, and locally rooted knowledge systems of the natural world. Local people are increasingly being recognized as partners in more comprehensive efforts towards sustainable management; an approach generally termed as 'community-based conservation' (Mehta and Kellert 1998). The approach is based on the principle that conservation strategies should emphasize the role of local communities in decision-making towards conservation (Adams and Hulme 1998), and indigenous communities can be involved as active partners in protected area management (Murphree 1995; Songorwa et al. 2000). Community-based conservation programs could effectively achieve its goals by (i) allowing people living in and around protected areas to participate in land-use policy and management decisions, (ii) giving people proprietorship or ownership over wildlife 
resources, and (iii) providing local people with economic benefits from wildlife conservation (Hackel 1998).

Moreover, there is evidence that indigenous people's role as nature conservationists can be easily undermined by counter-examples such as species extinction due to human hunting in the prehistoric past and giving grants on extensive timber cutting or mining concessions on their lands. Indigenous people have a variety of reactions to these claims (Cunningham 2001). Some studies adopt a more pragmatic stance that stresses the practicality and urgency of coordinating local communities and conservationists (Orlove and Brush 1996).

In the Philippines, Manobos are the largest ethnic group based on the relationships and ethnolinguistic branching and distribution. The group occupies a wide range of distribution but is localized in some regions and has assumed the character of distinctiveness as a separate ethnic grouping such as the Bagobo or the Higaonon and the Atta (Elkins 1964). These tribes are typically forestdwellers and reside near protected areas. They usually live on timber and non-timber forest products. Although their cultural background is well explored, the knowledge and perception of the Manobo tribe on biodiversity conservation are not well understood. Thus, this study aims to determine the knowledge and perception of this indigenous group on biodiversity conservation, which is necessary to evaluate the various perspectives of indigenous people on this matter. Traditional knowledge and perception towards diversity can be a helpful foundation in developing adaptive management strategies. Moreover, this will be an excellent basis to develop and implement community-based conservation management with the involvement of indigenous people since most of these communities live within or in the vicinity of protected areas and biodiversity hotspots.

\section{MATERIALS AND METHODS}

\section{Location of the study}

The study was conducted in Brgy. Bentangan, Carmen, North Cotabato (Figure 1). Bentangan is one of the twentyeight barangays of Carmen, North Cotabato, Philippines, located at 7.3250 N and 124.6941 E. The area is inhabited by the Tri-people group composed of Christians, Muslims, and Arumanen-Manobo ethnic group. The area belongs to a type III climate wherein seasons are not very pronounced, relatively dry from November to April, and wet during the rest of the year. Karstic hills bound the area with fertile soil utilized mainly for agriculture. There are forest patches along valleys and river banks with reported wildlife. Most settlement areas are located near agricultural lands. There are no major roads near the site, and farm-to-market roads are not concrete.

\section{Respondents and sampling procedure}

Prior informed consent was sent to barangay (Filipino term for the lowest government unit in the Philippines) and community leaders. The study's rationale was presented as part of the requirements for securing a survey permit. We surveyed a total of 100 randomly selected individuals belonging to the Manobo tribe to interview. Respondents were validated by barangay officials and tribal leaders as members of the Manobo tribe.

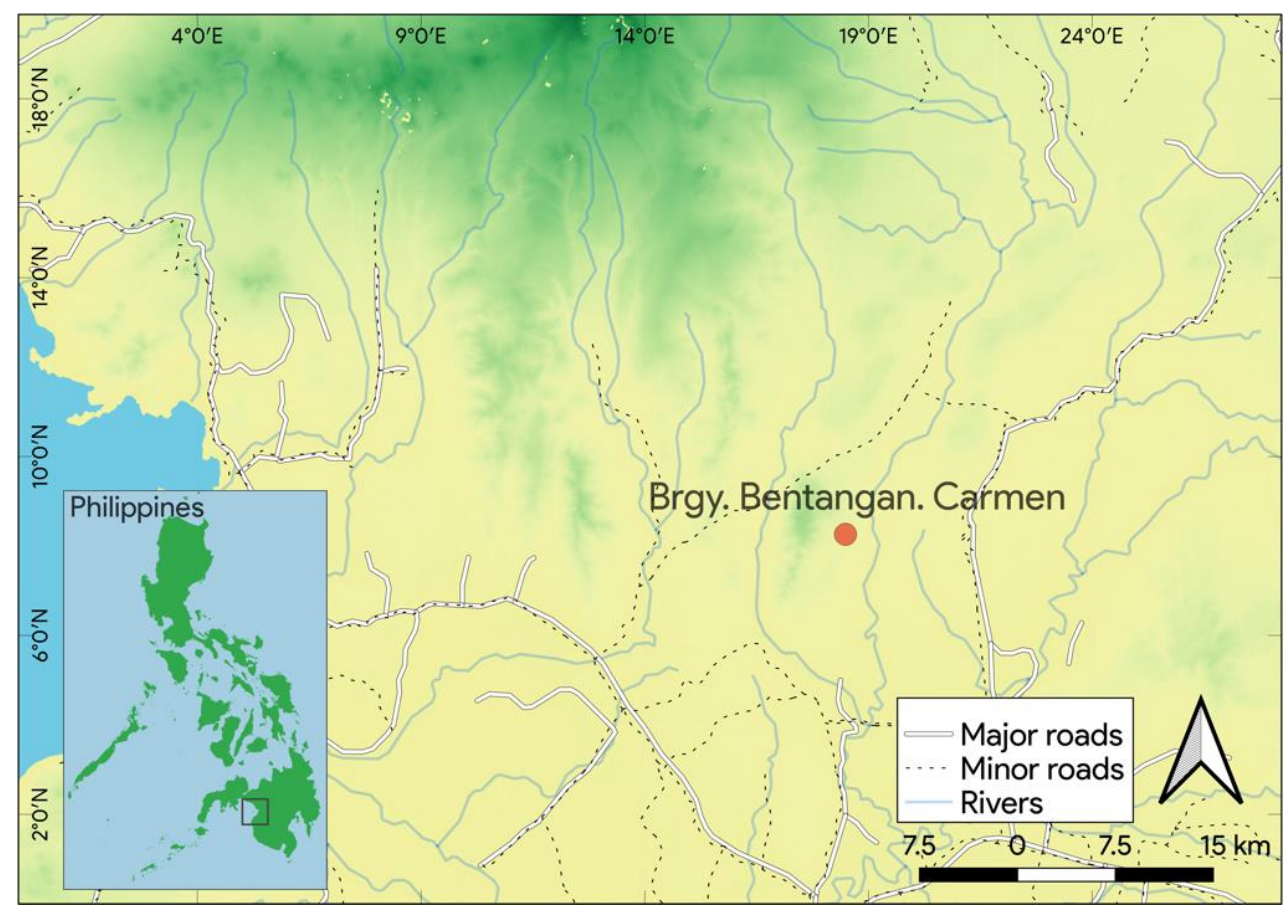

Figure 1. Map of the sampling site showing the relative distance to nearest roads. Map was generated using QGIS 3 
Table 1. Summary of reliability test across indicators of biodiversity knowledge and overall perception of biodiversity importance

\begin{tabular}{ll}
\hline Variables & Cronbach's $\boldsymbol{\alpha}$ \\
\hline (1) Knowledge of Biodiversity & 0.8589 \\
(2) Understanding of threats to Biodiversity & 0.8574 \\
(3) Understanding the role of Biodiversity in sustainable development & 0.8636 \\
(4) Efforts and policies are important for Biodiversity conservation & 0.8485 \\
(5) Traditional knowledge is important for biodiversity conservation & 0.9066 \\
(6) General Perception of the Importance of Biodiversity & 0.9159 \\
\hline
\end{tabular}

Using a validated semi-structured questionnaire adapted from Turner-Erfort (1997) and Halim et al. (2012), modifications, levels of knowledge, and perception were measured. The questionnaire consisted of three parts: (i) sociodemographic profile of each respondent (e.g., gender, age, religious affiliation, years of residency, and educational attainment); (ii) Part 2 of the questionnaire consisted of ten statements regarding respondent's knowledge on biodiversity aspects (e.g., Biodiversity can be understood as biological in nature) and respondents' indicated strongly agree, agree, disagree or strongly disagree with each statement; and (iii) Part 3 of the questionnaire consisted of ten statements regarding respondent's perception on the importance of biodiversity (e.g., Maintaining biodiversity is needed for the sustainable utilization of natural resources) and respondents indicated very important, important, slightly important or not important with each statement.

A face-to-face interview was conducted with each respondent. Clarification on each statement on knowledge and perception towards biodiversity was done when needed.

Of the 100 respondents, sixty percent $60 \%$ ) were female and forty percent $(40 \%)$ were male respondents. Most of the respondents belonged to the age group of $<20$ years old $(52 \%)$. Other respondents were $>20-40$ years old $(31 \%)$ and $>40$ years old (29\%). Regarding their religious affiliation, $83 \%$ of the respondents were Langkat (religious movement of the Manobos); $10 \%$ were Roman Catholic; $3 \%$ were UCCP; $2 \%$ were Protestants, and $2 \%$ were Muslims. Fifty $(50 \%)$ of the respondent were residents in the area for 10-19 years. Others were residents in the area for 1-9 years (20\%) and 20-29 years $(20 \%)$ in the area. In terms of educational attainment, $60(60 \%)$ out of 100 were high school level, 21 (21\%) were elementary level and 7 (7\%) were college level.

\section{Statistical analysis}

Before statistical analyses, categorical responses were transformed to numerical scales (4= Strongly Agree/Very Important - 1= Strongly Disagree/Not Important). Some statements on biodiversity were lumped to develop a more reliable statistical model. Using Cronbach's alpha coefficient was employed to test the reliability and internal consistency of the items in the questionnaire. Based on the reliability test, the overall alpha-value is 0.896 . This indicates that all indicators of biodiversity knowledge and general perception of biodiversity importance (Table 2). To determine the significant difference in responses across demographic scales, a non-parametric Kruskal-Wallis test was used. Categorical classifications of sociodemographic remained the same except we transformed "Age" into three categories $(A=<20, B=>20-40$, and $C=>40)$. A stepwise general linear regression was to determine tpublicrminants of public perception on the importance of biodiversity using local understanding variables to predict biodiversity (e.g., Sakurai et al. 2013). We used the open software JASP (version 0.11) statistical to perform all reliability and statistical tests. All significance was set at $p=0.05$.

\section{Ethical note}

Before the personal interviews, each respondent was briefed on the purpose of the research Respondents were informed of their rights to discontinue the interview if deemed necessary. All responses provided by the respondents were kept in an envelope, and only an authorized person could access it.

\section{RESULTS AND DISCUSSION}

\section{Results}

Based on the computed mean responses (Figure 2), it was observed that female respondents have greater knowledge on biodiversity $(\bar{x}=3.43)$, perceived that traditional knowledge $(\bar{x}=3.53)$ and related policies $(\bar{x}$ $=3.35)$ are important for biodiversity conservation $(\bar{x}$ $=3.53$ ), and overall perception on the importance of biodiversity $(\bar{x}=3.54)$. They also have a better understanding of the relationship between biodiversity and sustainability $(\bar{x}=3.56)$. It was also observed that female respondents have a better understanding on possible threats to biodiversity $(\bar{x}=3.4)$. According to age category (Figure 3 ), category B (>20-40 years old) have greater knowledge on most aspect of biodiversity including threats to biodiversity (3.02), on the importance of related policies (3.22) and traditional knowledge (3.48) on conservation, and overall perception towards biodiversity importance (3.59). While, computed mean response according to religious affiliation (Figure 4) showed that respondents from United Christian Church of the Philippines, Inc. (UCCP) have greater knowledge on biodiversity (3.44), better understanding of biodiversity threats (3.0), the link between biodiversity and sustainability (3.67), and perceived that policies related to biodiversity (3.17) and traditional knowledge (3.67) are important for conservation. However, protestants have higher mean response in terms of overall perception of the importance of biodiversity (3.65). In terms of educational attainment 
(Figure 5), respondents with higher educational attainment have tended to have college graduates have greater knowledge on biodiversity (3.93), threats to biodiversity (3.9), and perceived that policies towards biodiversity (3.8) and traditional knowledge (4.0) are important for conservation. In terms of overall perception of the importance of biodiversity, respondents who are elementary graduates have higher mean response (4.0).

Based on the result of Kruskal-wallis test (Table 2), there was a significant difference on the mean responses towards biodiversity according to gender and educational attainment. In terms of the general perception of the importance of biodiversity, there was a significant difference in the mean response according to gender.

Furthermore, general multiple regression model showed that independent variables are associated with overall importance perception of respondents $\left(R^{2}=0.34, F_{(9,90)}\right.$ $=5.6935 p<.0001)$ but only "importance of traditional knowledge biodiversity" conservation showed strong positive association $(\beta=0.32, \mathrm{p}<.01)$.

Table 2. Non-parametric Kruskal-Wallis Test on the significant difference across sociodemographic scales in different indicators of biodiversity knowledge and overall perception of biodiversity importance. ( $P$ values with $* *$ indicates significance)

\begin{tabular}{|c|c|c|c|}
\hline & Statistic & df & p-value \\
\hline \multicolumn{4}{|c|}{ (1) Knowledge of Biodiversity } \\
\hline Gender & 19.272 & 1.000 & $0.001 * *$ \\
\hline Age & 5.542 & 2.000 & 0.063 \\
\hline Religion & 0.958 & 4.000 & 0.916 \\
\hline Educational Attainment & 37.492 & 5.000 & $0.001 * *$ \\
\hline \multicolumn{4}{|c|}{ (2) Understanding of threats to Biodiversity } \\
\hline Gender & 48.736 & 1.000 & $0.001 * *$ \\
\hline Age & 1.080 & 2.000 & 0.583 \\
\hline Religion & 1.139 & 4.000 & 0.888 \\
\hline Educational Attainment & 39.187 & 5.000 & $0.001 * *$ \\
\hline \multicolumn{4}{|c|}{ (3) Understanding on the role of Biodiversity in sustainable development } \\
\hline Gender & 13.570 & 1.000 & $0.001 * *$ \\
\hline Age & 4.940 & 2.000 & 0.085 \\
\hline Religion & 1.090 & 4.000 & 0.896 \\
\hline Educational Attainment & 36.214 & 5.000 & $0.001 * *$ \\
\hline \multicolumn{4}{|c|}{ (4) Efforts and policies are important for Biodiversity conservation } \\
\hline Gender & 39.674 & 1.000 & $0.001 * *$ \\
\hline Age & 3.572 & 2.000 & 0.168 \\
\hline Religion & 2.802 & 4.000 & 0.592 \\
\hline Educational attainment & 32.150 & 5.000 & $0.001 * *$ \\
\hline \multicolumn{4}{|c|}{ (5) Traditional knowledge is important for biodiversity conservation } \\
\hline Gender & 4.940 & 1.000 & $0.026 * *$ \\
\hline Age & 1.662 & 2.000 & 0.436 \\
\hline Religion & 4.732 & 4.000 & 0.316 \\
\hline Educational attainment & 11.357 & 5.000 & $0.045^{* *}$ \\
\hline \multicolumn{4}{|c|}{ (6) General Perception on the Importance of Biodiversity } \\
\hline Gender & 5.187 & 1.000 & $0.023 * *$ \\
\hline Age & 3.901 & 2.000 & 0.142 \\
\hline Religion & 2.124 & 4.000 & 0.713 \\
\hline Educational attainment & 6.192 & 5.000 & 0.288 \\
\hline
\end{tabular}

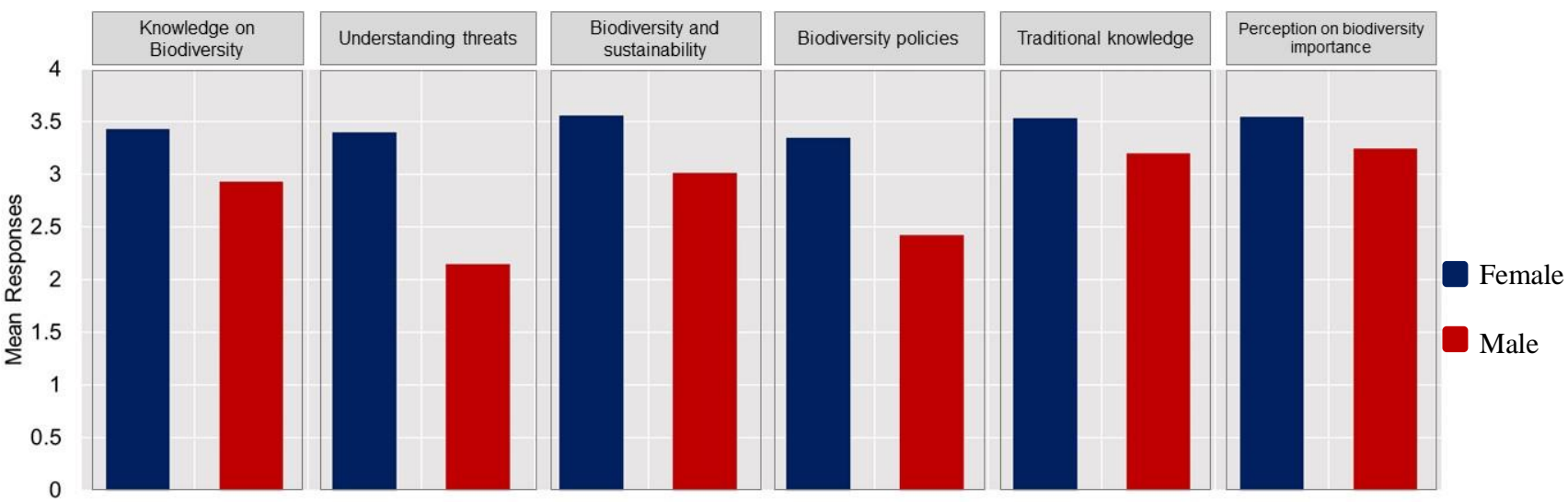

Figure 2. Levels of knowledge and perception importance on biodiversity according to gender (expressed in $\bar{x}$ values where 4 as "strongly agree") 


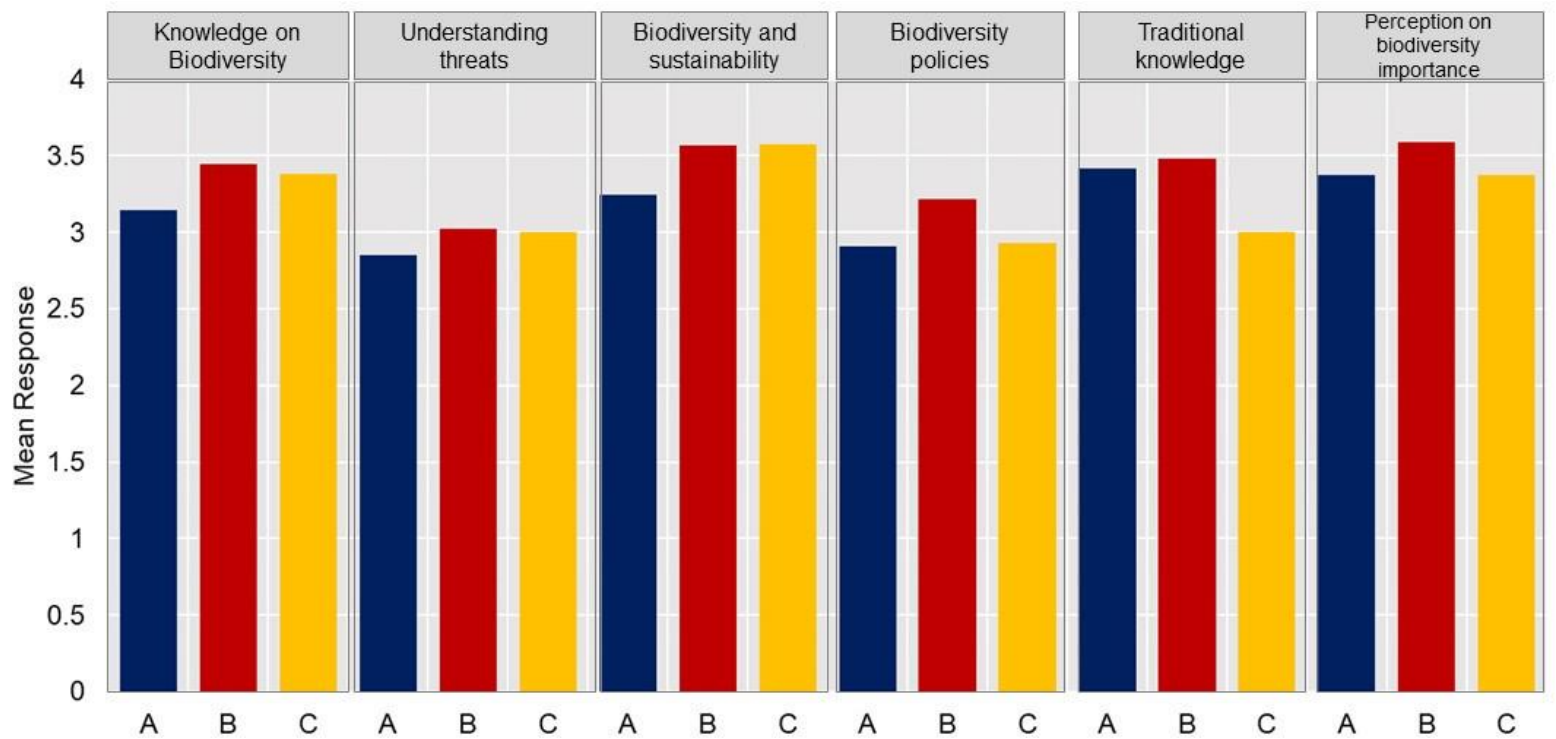

Figure 3. Knowledge on biodiversity and perception on biodiversity importance according to age category (A- $<20$ years old; B- >20-40 years old; C- >40 years old)

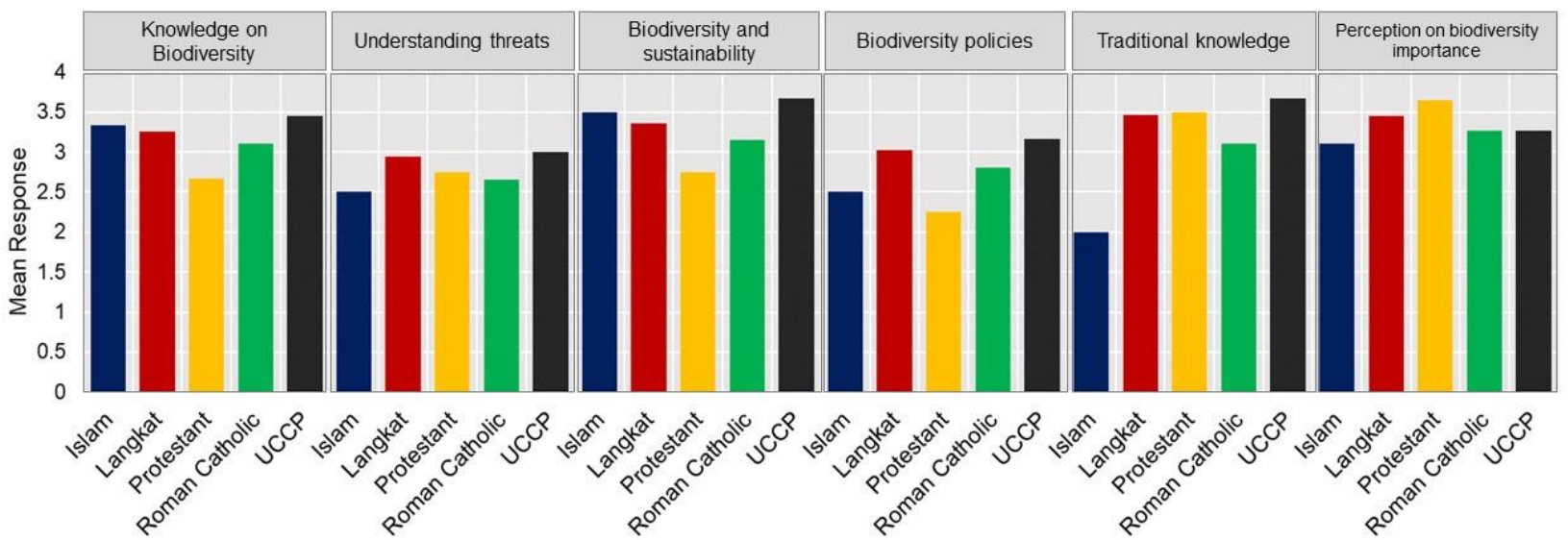

Figure 4. Knowledge of biodiversity and perception of biodiversity importance according to religious affiliation

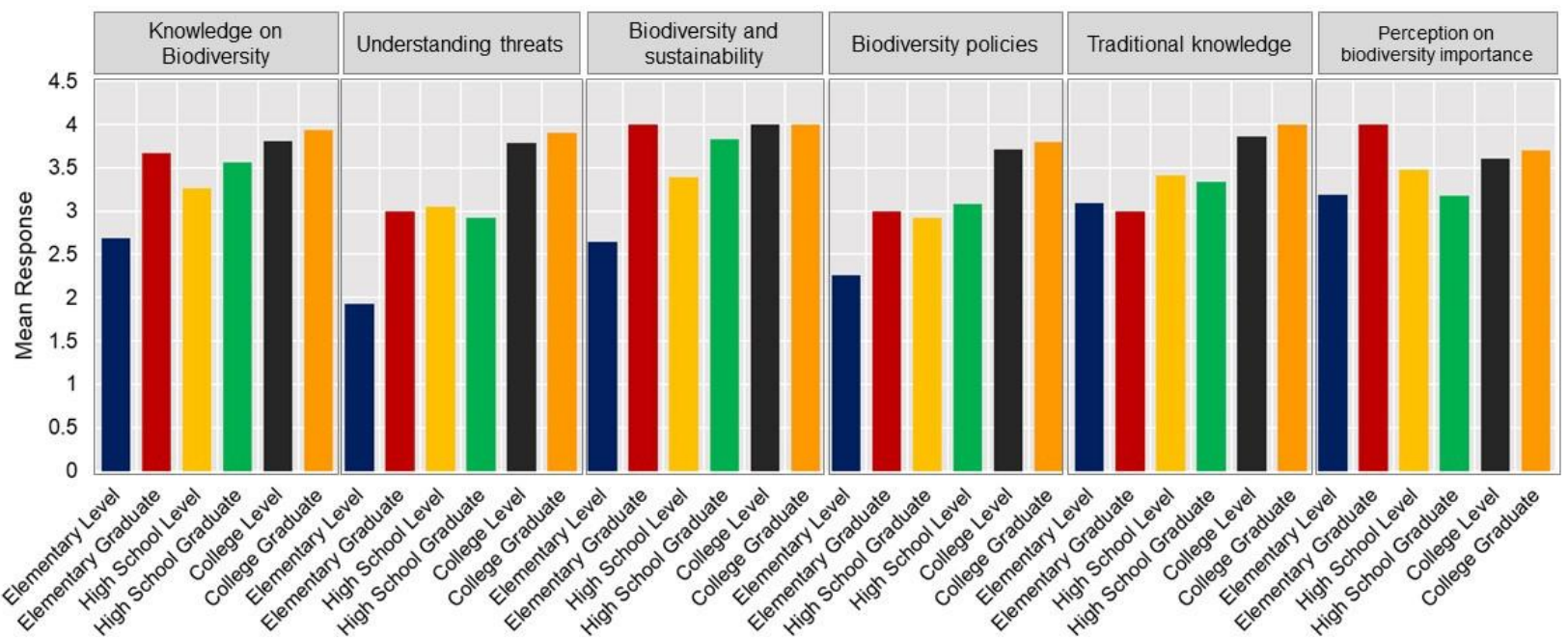

Figure 5. Knowledge of biodiversity and perception of biodiversity importance according to educational attainment. 
Table 3. General multiple linear regression on the association of local biodiversity understanding to general perception on the importance of biodiversity. ( $P$ values with $* *$ indicates significance. $R^{2}=0.363$, Mean square $=1.3418, F=5.6935$. Note: $\beta=$ standardized coefficient, $\mathrm{SE}=$ Standard Error)

\begin{tabular}{lllll}
\hline & $\boldsymbol{\beta}$ & SE & $\mathbf{t}$ & $\mathbf{p}$-value \\
\hline (Intercept) & 0.51 & 3.27 & 0.01 \\
Gender & -0.04 & 0.18 & -0.25 & 0.80 \\
Religion & -0.05 & 0.06 & -0.54 & 0.59 \\
Age & 0.12 & 0.00 & 1.37 & 0.17 \\
Educational attainment & -0.15 & 0.05 & -1.27 & 0.21 \\
Knowledge on biodiversity & 0.35 & 0.30 & 1.21 & 0.23 \\
Understanding of threats to biodiversity & 0.17 & 0.15 & 0.74 & 0.46 \\
Understanding the role of biodiversity in sustainable development & -0.34 & 0.20 & -1.49 & 0.14 \\
Efforts and policies are important for biodiversity conservation & 0.25 & 0.18 & 1.09 & 0.28 \\
Traditional knowledge is important for biodiversity conservation & 0.32 & 0.09 & 3.03 & $0.01 * *$ \\
\hline
\end{tabular}

\section{Discussion}

There was a significant difference in the mean responses on knowledge and perception towards biodiversity according to gender and educational attainment. It was observed that female respondents have higher mean responses on both knowledge and perception towards biodiversity. This result is in agreement with the study of Lim and Wilson (2019) wherein females significantly viewed the importance of bats in fruit production compared to males. Murphy (2004) also added that females are more knowledgeable and tend to have more positive attitude towards environment. In terms of educational attainment, respondents with higher educational attainment were more knowledgeable and have better understanding of the aspects of biodiversity. Increased ecological and biodiversity knowledge can be acquired through formal education which can be used in developing educational programs related to biodiversity (Pinheiro et al. 2016). In the case of Kenya, compulsory biology courses possibly increase positive attitudes towards biodiversity, like perception towards bats (Prokop and Tunnicliffe 2008). Among the respondents, those who were elementary graduates have higher mean response on the overall perception of the importance of biodiversity. This result indicates that even at the lower educational level, the importance of biodiversity has been discussed and taught. In addition, respondents with lower educational levels have been involved in some activities related to biodiversity conservation which may have contributed to their perception. It is also possible that perception of the importance of biodiversity is a result of traditional knowledge transfer from elder Manobos.

It is interesting to note that traditional knowledge of Manobo tribe significantly affects their perception of the importance of biodiversity. This can support the aforementioned statement on the perception of Manobo on the importance of biodiversity. This indicates that Manobo tribe believes that their traditional knowledge has a big contribution to preserving biodiversity which they can use as a source of basic needs. In the study of Ruddle and Johannes (1990), many indigenous people are dependent on traditional knowledge and practices in caring for their traditional territories, and for the harvesting of wild food and animals, medicines, water, and other basic needs to preserve their environment and biodiversity. There are traditional activities conducted by the Manobo tribe that balance ecological cycles. It indicates that biodiversity is very important for them since it is also part of the survival of the present and future generations aside from being the source of their basic needs. This result is in agreement with the study of Elder et al. (1998) which stated that the indigenous people's meaning of biodiversity is not connected to scientific definitions but anchored to the respondents' daily practices, experiences, knowledge, and emotions.

Perception of the importance of biodiversity can be associated with biodiversity conservation and according to Jordan (1988), conservation has a critical role to play in maintaining biodiversity. However, it is not an adequate strategy in conserving biological diversity. Eventually, there is a need for a way of putting pieces back together when something has been altered, damaged, or even destroyed as what Manobo does to conserve their biodiversity. Biodiversity is of global importance for humanity as a whole, for the maintenance of ecosystem services.

The results of this study indicate that biodiversity and culture can be related. Most discussions on the complex relationship between the conservation of biodiversity and cultural diversity center on the argument that cultural diversity can sustain a wide variety of practices that promote conservation of natural resources (Posey 1999). An example is how different 'indigenous' groups around the world have protected those species and habitats related to their cultural beliefs which provide an insight into the relationship and role of human diversity in the conservation of biodiversity. Manobos perceived that forest ecosystem and protection of species and habitats are important aspects that linked to cultural beliefs which provide insights on the connection and role of humans in biodiversity conservation. This is related to the statement of Posey (1999) wherein different cultures perceived and appreciate biodiversity in different ways because of their distinct heritage and experiences. As stated by the ASEAN Centre for Biodiversity (2010), the abundance of these diverse biological resources also ensures the continuous flow of goods and ecosystems services for the benefit of the present and future generations which can be done through 
community-based conservation management. Some studies revealed that many indigenous communities depend directly on natural ecological systems for their sustenance. In Sabah, Malaysia, indigenous people have developed their unique indigenous systems for a sustainable livelihood (Halim et al. 2012). However, indigenous communities have scanty resources and few options to adapt (financially, technically and socially) by themselves where most adaptive strategies constitute local knowledge. Studies revealed that many indigenous communities depend directly on natural ecological systems for their sustenance. In this context, Geronimo et al. (2016) stressed that biological diversity and natural ecosystems are closely linked to the economy, identity, cultural and spiritual values, as well as the social organization of indigenous people.

Implementation of biodiversity conservation measures is often challenged through fierce debate and resistance to specific management approaches (Stoll-Kleemann 2001; Miller 2005; Lindström et al. 2006; Marshall et al. 2007). This lack of support at the local level has been linked to the seemingly inadequate knowledge of the general public about biodiversity, suggesting that the public might not have enough insight to appreciate the benefits of biodiversity and its conservation (DEFRA 2002; Hunter and Brehm 2003). Some studies examined this phenomenon describing individuals' understanding of biodiversity as an isolated concept.

In general, the result of this study indicates that traditional knowledge has a significant role in the perception of Manobo tribe on the importance of biodiversity, thus, conservation as well. Practices and beliefs that have been embedded in the indigenous knowledge among indigenous communities, particularly the Manobo tribe are good examples to establish biodiversity conservation and environmental obligations. The community of Brgy. Bentangan is the best venue for implementation of community-based conservation management since it is one of the vicinity of protected areas and biodiversity hotspots.

\section{ACKNOWLEDGEMENTS}

The research team would like to express their gratitude to all individuals who have contributed to the completion of the study especially to tribal leaders, barangay captains, and the respondents. Special thanks to Krizler C. Tanalgo for his valuable contribution to this paper.

\section{REFERENCES}

Adams WM, Hulme D. 1998. Conservation and Communities: Changing Narratives, Policies and Practices in African Conservation. Community Conservation in Africa: Principles and Comparative Practice. Discussion Paper no. 4, IDPM. University of Manchester, Manchester. DOI: 10.1046/j.1365-3008.2001.00183.x.

ASEAN Centre for Biodiversity. 2010. Conserving and managing biodiversity at the regional level. First ASIAHORCS Joint Symposium, 18-20 July 2009, Nagoya, Japan. https: //www.jsps.go.jp/english/e-

astrategy/date/07_asiahorcs_03_p1/keynote/keynote1_Fuentes.pdf

Bille R, Layere R, Pirard R. 2012. Biodiversity conservation and poverty alleviation: A way of the deadlock? Sapiens 5 (1): 1-15.

Butchart SH, Walpole M, Collen B, van Strien A, Scharlemann JP, Almond RE, Baillie JE, Bomhard B, Brown C, Bruno J, Carpenter KE, Carr GM, Chanson J, Chenery AM, Csirke J, Davidson NC, Dentener F, Foster M, Galli A, Galloway JN, Genovesi P, Gregory RD, Hockings M, Kapos V, Lamarque JF, Leverington F, Loh J, McGeoch MA, McRae L, Minasyan A, Hernández Morcillo M, Oldfield TE, Pauly D, Quader S, Revenga C, Sauer JR, Skolnik B, Spear D, Stanwell-Smith D, Stuart SN, Symes A, Tierney M, Tyrrell TD, Vié JC, Watson R. 2010. Global biodiversity: indicators of recent declines. Sci 328 (5982): 1164-1168. DOI: 10.1126/science.1187512.

Cunningham AB. 2001. Applied Ethnobotany: People, Wild Plant Uses and Conservation. Earthscan, London, UK.

Department for Environment Food and Rural Affairs (DEFRA). 2002. Wild Bird Index. In Achieving a better quality of life. Review of progress towards sustainable development. Government Annual Report 2002. DEFRA, UK

Elder J, Coffin C, Farrior M. 1998. Engaging the Public on Biodiversity: a road map for education and communication strategies. Biodiversity Project, Madison.

Elkins R. 1964. The Anit Taboo: A Manobo cultural unit. Pract Anthropol 11 (4): 185-188.

Garnett ST, Burgess ND, Fa JE, Fernández-Llamazares Á, Molnár Z, Robinson CJ, et al. 2018. A spatial overview of the global importance of Indigenous lands for conservation. Nat Sustain 1 (7): 369- 374. 10.1038/s41893-018-0100-6.

Garrity DP. 2001. A social contract for biodiversity: Institutional solutions to environmental conservation in the Philippines. SANREM CRSP, USA.

Geronimo MC, Cabansag MGS, Reyes AS. 2016. Indigenous utilization of resources and conservation practices of the Agta of Lupigue, Iligan City, Isabela, Philippines. Intl J Educational Stud 8 (2). www.mindamas-journals.com/index.php/educare

Hackel JD. 1998. Community conservation and the future of Africa's wildlife. Conserv Biol 13: 726-734. DOI: 10.1046/j.15231739.1999.98210.x.

Halim AAB, Othman N, Ismail SR, Jawan JA, Ibrahim NN. 2012. Indigenous knowledge and biodiversity conservation in Sabah, Malaysia. Int J Soc Sci Humanity 2 (2): 159-163. DOI: 10.7763/IJSSH.2012.V2.88.

Home R, Keller C, Nagel P, Bauer N, Hunziker M. 2009. Selection criteria for flagship species by conservation organizations. Environ Conserv 36 (2): 139-148. DOI: 10.1017/S0376892909990051.

Hunter LM, Brehm JM. 2003. Brief Comment: Qualitative insight into public knowledge of, and concern with, biodiversity. Hum Ecol 31 (2): 309-320. DOI: 10.1023/A:1023988914865.

International Fund for Agricultural Development (IFAD). 2014. Highlights Annual Report 2014. https: //beta.ifad.org/documents/38714170/39625423/Highlights+AR+2014 _E.pdf/74576162-ae01-48a8-8db9-acd53a250682

Jaisankar J, Velmurugan A, Sivaperuman C. 2018. Biodiversity Conservation: Issues and strategies from the tropical Islands. In: Biodivers Clim Change Adapt Trop Isl. Academic Press, New York. DOI: 10.1016/B978-0-12-813064-3.00019-3.

Jordan C. 1988. Ecosystem Ecology. In: Conservation Biology. DOI: 10.1111/j.1523-1739.1988.tb00163.x.

Lim VC, Wilson JJ. 2019. Public perception and Knowledge of, and responses to, bats in urban areas in Peninsular Malaysia. Anthozoos 32 (6): 825-834. DOI: 10.1080/08927936.2019.1673063.

Lindström M, Johansson M, Herrmann J, Johnsson O. 2006. Attitudes towards the conservation of biological diversity-A case study in Kristianstad Municipality, Sweden. J Environ Plann Manag 49 (4): 495-513. DOI: 10.1080/09640560600747893.

Marshall K, White RM, Fischer A. 2007. Conflicts between humans over wildlife management: On the diversity of stakeholder attitudes and implications for conflict management. Biodivers Conserv 16911: 3129-3146. DOI: 10.1007/s10531-007-9167-5.

Mehta J, Kellert S. 1998. Local attitudes toward community-based conservation policy and programmes in Nepal: a case study in the Makalu-Barun Conservation Area. Environ Conserv 25 (4): 320-333. DOI: $10.1017 /$ S037689299800040X. 
Miller JR. 2005. Biodiversity conservation and the extinction of experience. Trends Ecol Evol 20 (8): 430-434. DOI: 10.1016/j.tree.2005.05.013.

Murphree MW. 1995. Optimal principles and pragmatic strategies. Creating an enabling politico-legal environment for community based natural resource management. In: Rihoy E. (ed.) The Commons without the Tragedy. Strategies for community based natural resources management in Southern Africa. SADC Wildlife Technical Coordination Unit, Malawi.

Murphy TP. 2004. The second Minnesota report card on environmental literacy: A survey of adult environmental knowledge, attitude and behavior. Minnesota Office of Environmental Assistance, Minnesota USA.

Myers N, Mittermeier R, Mittermeier C, da Fonseca G, Kent J. 2000 Biodiversity hotspots for conservation priorities. Nature 403: 853858. DOI: $10.1038 / 35002501$.

Orlove BS, Brush S. 1996. Anthropology and the conservation of Biodiversity. Annu Rev Anthropol 25: 329-352. DOI: 10.1146/annurev.anthro.25.1.329

Pinheiro LT, Rodrigues JFM, Borges-Nojosa DM. 2016. Formal education, previous interaction and perception influence the attitudes of people toward the conservation of snakes in a large urban center of northeastern Brazil. J Ethnobiol Ethnomed 12: 25. DOI: 10.1186/s13002-016-0096-9. DOI: 10.1186/s13002-016-0096-9.

Posa MR, Diesmos A, Sodhi N, Brooks T. 2008. Hope for threatened tropical biodiversity: Lessons for the Philippines. BioSci 58 (3): 231240. DOI: 10.1641/B580309.

Posey DA. 1999. Cultural and spiritual values of biodiversity. A complementary contribution to the global biodiversity assessment. In: Posey DA (ed) Cultural and Spiritual Values of Biodiversity, UNEP and Intermediate Technology Publications, London, UK. DOI: 10.3362/9781780445434.000.

Prokop P, Tunnicliffe SD. 2008. "Disgusting" animals: Primary school children's attitudes and myths of bats and spiders. Eurasia J Math Sci Technol Educ 4 (2): 87-97. DOI: 10.12973/ejmste/75309.

Ruddle K, Johannes R. 1990. Traditional Marine Resource Management in the Pacific Basin: An Anthology. UNESCO-ROSTSEA, Jakarta.

Russell J, Yates CP, Edwards AC, Whitehead PJ, Murphy BP, Lawes MJ. 2015. Deriving multiple benefits from carbon market-based savanna fire management: An Australian example. PLoS One 10 (12): e0143426. DOI: 10.1371/journal.pone.0143426.

Sakurai T, Nakada T, Fujikoshi Y. 2013. High-dimensional AICs for selection of variables in discriminant analysis. Sankhya Series A 75: 1-25. DOI: 10.1007/s13171-013-0025-0.

Secades C, O’Connor B, Brown C, Walpole M. 2014. Earth observation for biodiversity monitoring: A review of current approaches and future opportunities for tracking progress towards the Aichi biodiversity targets. Technical Series No. 72. http: //www.cbd.int/doc/publications/cbd-ts-72-en.pdf

Shafer CL. 1990. Nature Reserves. Island Theory and Conservation Practice. Smithsonian Institution Press, Washington.

Songorwa AN, Buhrs T, Hughey KFD. 2000. Community-based wildlife management in Africa: a critical assessment of the literature. Nat Resour 40 (3): 603-643

Stoll-Kleemann S. 2001. Opposition to the designation of protected areas in Germany. J Environ Plann Manag 44 (1): 109-128. DOI: 10.1080/09640560123606.

Turner-Erfort G. 1997. Public awareness and perceptions of biodiversity. Trans Illinois State Acad Sci 90 (3): 113-121. 